\title{
PENGARUH PELATIHAN TERHADAP KINERJA KARYAWAN PADA HOTEL SANTIKA \\ PREMIERE DYANDRA MEDAN
}

\author{
Efin Shu, Wardayani,Benni Ichsanda Rahman \\ Alumni Sekolah Tinggi Ilmu Manajemen Sukma \\ Program studi Manajemen, Sekolah Tinggi Ilmu Manajemen \\ wardayani302@,gmail.com, ichsandabenny@gmail.com
}

\begin{abstract}
The purpose of this research is to find out if the impact of training towards employees' performance at Santika Premiere Dyandra Hotel Medan. The samples of this research are 38 Front of House employees. Sampling technique is incidental sampling which is a sample determination technique based on chance, i.e. anyone whom are accidentally/ incidentally met by the researcher can be used as a sample, when viewed as appropriate to be data source. Data analysis using quantitative descriptive with the model of Simple Regression test analysis, hypothesis test using coefficient of determination test $\left(R^{2}\right)$ and partial test ( $t$ test), while data processing using SPSS 2.2. Based on Partial Test ( $t$ test), the result of this research shows that partially, training has positive effects towards Front of House employees' performance at Santika Premiere Dyandra Hotel Medan. However, based on Coefficient of Determination test $\left(R^{2}\right)$, training variable has a little impact towards performance variable at Santika Premiere Dyandra Hotel Medan. This is proven by the coefficient determination value of 0,092.
\end{abstract}

Key words: training, performance, and Santika Premiere Dyandra Hotel Medan.

\section{PENDAHULUAN}

Industri jasa adalah industri yang sangat berkembang di era globalisasi ini. Hal ini seiring dengan perubahan gaya hidup yang semakin modern dan standar kehidupan yang semakin meningkat. Salah satu industri yang bergerak di bidang jasa adalah industri perhotelan. Industri perhotelan merupakan salah satu industri yang sangat berkembang di kota Medan. Hal ini dapat dibuktikan dengan semakin banyak hotel yang dibangun di kota Medan. Sebagai suatu industri yang sangat mengandalkan sumber daya manusianya atau juga disebut human touch industry or labor intensive industry, pelatihan sangat dibutuhkan di dalam memastikan kualitas pelayanan karyawan terhadap tamu. Mengingat kelemahan manusia yang cenderung tidak konsisten menjadikan pelatihan sangat penting agar karyawan dapat memenuhi standar dan konsistensi pelayanan di hotel.

Penelitian yang dilakukan oleh Fadli et al (2015) dengan judul "Pengaruh Pelatihan Terhadap Kinerja Karyawan Hotel Grand Cempaka Resort \& Convention Cipayung Bogor" menyatakan bahwa terdapat pengaruh nyata dan positif antara pelatihan dan kinerja karyawan pada Hotel Grand Cempaka Resort \& Convention Cipayung Bogor. Penelitian yang dilakukan oleh Saputra (2015) dengan judul "Pengaruh Pelatihan Terhadap Kinerja Karyawan Kurir Perusahaan PT.TIKI (Titipan Kilat) Kota Sukabumi" menyatakan bahwa variable pelatihan berpengaruh signifikan terhadap kinerja karyawan, hal ini ditunjukan melalui hasil analisis statistik. Penelitian yang dilakukan oleh Triasmoko (2014) dengan judul "Pengaruh Pelatihan Kerja Tehadap Kinerja Karyawan (Penelitian Pada Karyawan PT Pos Indonesia (Persero) Cabang Kota Kediri)" menyatakan bahwa ada pengaruh secara simultan dan parsial antara pelatihan kerja yang terdiri dari variabel metode pelatihan, materi pelatihan dan instruktur pelatihan terhadap kinerja karyawan PT Pos Indonesia (Persero) Cabang Kota Kediri. 
Penelitian yang dilakukan oleh Wulandari dan Alamanda (2012) dengan judul "Pengaruh Pelatihan dan Disiplin Kerja Terhadap Kinerja Karyawan Pada Yayasan Pendidikan Telkom" menyatakan bahwa hasil penelitian dengan menggunakan regresi analisa berganda menunjukkan bahwa ada efek yang sangat kuat dan positif antara pelatihan kerja terhadap kinerja karyawan PT. Telkom sebesar 0.830. Penelitian yang dilakukan oleh Yulianti (2015) dengan judul "Pengaruh Pelatihan Terhadap Kinerja Karyawan Grand Fatma Hotel di Tenggarong Kutai Kartanegara" menunjukkan bahwa pelatihan berpengaruh signifikan terhadap kinerja karyawan Grand Fatma Hotel di Tenggarong.

\section{Perumusan Masalah}

Perumusan masalah penelitian ini yaitu apakah ada pengaruh pelatihan terhadap kinerja karyawan pada Hotel Santika Premiere Dyandra Medan?

\section{Batasan Masalah}

Penelitian ini hanya dibatasi pada karyawan bagian Front of House, yaitu Front Office, Housekeeping, Food and Beverage Service, dan Food and Beverage Product Departments.

\section{Tujuan Penelitian}

Adapun tujuan dari penelitian ini adalah untuk mengetahui pengaruhpelatihan terhadap kinerja karyawan bagian Front of House pada Hotel Santika Premiere Dyadra Medan.

\section{METODE PENELITIAN}

\section{Metode Pengumpulan Data}

Dalam penelitian ini, metode pengumpulan data yang digunakan adalah sebagai berikut:

1. Studi Dokumentasi: metode yang dilakukan dengan mencari informasi mengenai dokumen-dokumen perusahaan yang berkaitan dengan penelitian.

2. Kuesioner: metode yang dilakukan dengan membuat daftar pertanyaan dalam bentuk angket yang ditujukan kepada responden yang dijadikan sampel.

3. Wawancara: metode yang dilakukan dengan melakukan wawancara terhadap manajemen perusahaan.

\section{Definisi Operasional}

Sesuai dengan rumusan masalah, maka identifikasi variabel-variabel dalam penelitian ini adalah sebagai berikut:

1. Variabel bebas (variabel independen) sebagai variable yang mempengaruhi variable terikat, yang mana dalam penelitian ini adalah pelatihan atau training $(\mathrm{X})$;

2. Variabel terikat (variabel dependen) sebagai variable yang dipengaruhi oleh variable bebas, yaitu kinerja karyawan (Y).

3.

Tabel 1 Operasionalisasi Variabel Penelitian

\begin{tabular}{|c|l|l|l|l|}
\hline No & Variabel & \multicolumn{1}{|c|}{ Definisi } & Indikator & $\begin{array}{l}\text { Skala } \\
\text { Ukur }\end{array}$ \\
\hline 1. & $\begin{array}{l}\text { Pelatihan/ } \\
\text { training (X) }\end{array}$ & $\begin{array}{l}\text { Proses pengembangan } \\
\text { pengetahuan, keahlian, } \\
\text { sikap karyawan yang } \\
\text { diperlukan untuk } \\
\text { melaksanakan pekerjaan }\end{array}$ & $\begin{array}{l}\text { 1. Tujuan } \\
\text { sasaran yang } \\
\text { tercapai }\end{array}$ & Likert \\
2. & \multicolumn{2}{|c|}{$\begin{array}{l}\text { Pelatih } \\
\text { (trainers) }\end{array}$} & \\
\hline
\end{tabular}




\begin{tabular}{|c|c|c|c|c|}
\hline & & sesuai dengan posisinya. & $\begin{array}{l}\text { 3. Materi latihan } \\
\text { 4. Metode } \\
\text { pelatihan } \\
\text { 5. Peserta } \\
\text { pelatihan } \\
\text { (trainee) }\end{array}$ & \\
\hline 2. & Kinerja (Y) & $\begin{array}{l}\text { Hasil kerja secara kualitas } \\
\text { dan kuantitas yang dicapai } \\
\text { oleh seorang karyawan } \\
\text { yang dalam pelaksanaan } \\
\text { tugasnya sesuai dengan } \\
\text { tanggung jawab yang } \\
\text { diberikan kepada } \\
\text { karyawan bersangkutan. }\end{array}$ & $\begin{array}{l}\text { 1. Kualitas Kerja } \\
\text { 2. Ketepatan } \\
\text { Waktu } \\
\text { 3. Inisiatif } \\
\text { 4. Kemampuan } \\
\text { 5. Komunikasi }\end{array}$ & Likert \\
\hline
\end{tabular}

Sumber: Hayes dan Ninemeier (2016: 110), Mangkunegara (2013: 44-45), Mangkunegara (2013: 67), Mitchell dalam Sedarmayanti (2009:51)

\section{Uji Validitas dan Reliabilitas}

Menurut Sugiyono (2015:110) "uji validitas adalah suatu langkah pengujian yang dilakukan terhadap isi dari suatu instrument, dengan tujuan untuk mengukur ketepatan instrumen yang digunakan dalam suatu penelitian". Dikatakan valid jika nilai rhitung $\geq$ rtabel dan dikatakan tidak valid jika nilai rhitung $<$ rtabel.

Menurut Sugiyono (2012:111) "uji reliabilitas adalah proses pengukuran terhadap ketepatan (konsisten) dari suatu instrument". Dikatakan reliable jika nilai crombach alfa $>0.6$ dan dikatakan tidak reliabel jika nilai crombach alfa $<0.6$.

\section{Metode Analisis Data}

Metode analisis data yang digunakan dalam penelitian ini adalah metode deskriptif kuantitatif, sedangkan model analisis yang digunakan dalam penelitian ini adalah regresi sederhana. Menurut Sekaran dan Bougi (2016:313), "a simple linear regression equation represents a straight line." Model persamaannya adalah sebagai berikut:

$$
\begin{aligned}
& \text { Dimana: } \\
& \mathrm{Y}=\text { Kinerja } \\
& \mathrm{b}=\text { Koefisien regresi variabel pelatihan } \\
& \mathrm{X}=\text { Pelatihan } \\
& \mathrm{a}=\text { Konstanta } \\
& \mathrm{e}=\text { Error of term (toleransi tingkat kesalahan) }
\end{aligned}
$$

\section{Kerangka Berpikir}

Pelatihan yang berbasis kinerja akan meningkatkan kinerja, kepuasan tamu, reputasi perusahaan, keuntungan dan mengurangi biaya, masalah operasional, dan tingkat pergantian karyawan. Penelitian yang dilakukan oleh Suryoadi (2012) menunjukkan ada pengaruh positif dan signifikan pelatihan terhadap kinerja karyawan di Kantor Bank Muamalat Cabang Semarang. Penelitian yang dilakukan oleh Septian (2013) menunjukkan bahwa variabel pelatihan berpengaruh signifikan terhadap kinerja karyawan Erha Clinic, Bandung.

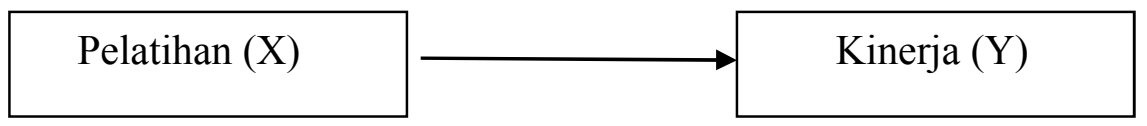

Gambar 3.1. Kerangka Berpikir 


\section{Hipotesis}

Menurut Sugiyono (2012:84) hipotesis adalah jawaban sementara terhadap rumusan masalah penelitian.

Berkaitan dengan pengertian di atas, maka hipotesis penelitian ini adalah "ada pengaruh pelatihan terhadap kinerja karyawan bagian Front of House Hotel Santika Premiere Dyandra Medan".

\section{Pengujian Hipotesis}

a. Koefisien Determinasi $\left(\mathrm{R}^{2}\right)$

Pada dasarnya, koefisien determinasi $\left(\mathrm{R}^{2}\right)$ mengukur seberapa besar kemampuan model dalam menerangkan variabel terikat. Semakin besar nilai koefisien determinasi (mendekati satu), maka dapat dikatakan bahwa pengaruh variabel bebas (X) adalah besar terhadap variabel terikat (Y).

b. Uji Parsial (Uji t)

Uji parsial (uji t) bertujuan untuk melihat pengaruh pelatihan terhadap kinerja karyawan, dengan kriteria:

1. Jika thitung $\leq$ ttabel maka $\mathrm{H}_{0}$ diterima, $\mathrm{H}_{1}$ ditolak, artinya secara parsial penelitian ini tidak berpengaruh;

2. Jika thitung $>$ ttabel maka $\mathrm{H}_{0}$ ditolak, $\mathrm{H}_{1}$ diterima, artinya secara parsial penelitian ini berpengaruh.

\section{HASIL DAN PEMBAHASAN}

\subsubsection{Dekripsi data variabel Pelatihan}

Untuk mengukur pelatihan, digunakan 5 indikator sesuai dengan teori yang ada. Berdasarkan pernyataan-pernyataan yang telah dijawab oleh responden, maka data yang dihasilkan adalah sebagai berikut:

Tabel 2 Rekapitulasi jawaban responden variable Pelatihan (x)

\begin{tabular}{|c|c|c|c|c|c|c|c|c|c|c|c|}
\hline \multirow[t]{2}{*}{ No } & \multirow[t]{2}{*}{ Pernyataan } & \multicolumn{2}{|c|}{$\begin{array}{l}\text { Sangat } \\
\text { Setuju }\end{array}$} & \multicolumn{2}{|c|}{ Setuju } & \multicolumn{2}{|c|}{$\begin{array}{c}\text { Kurang } \\
\text { Setuju }\end{array}$} & \multicolumn{2}{|c|}{$\begin{array}{l}\text { Tidak } \\
\text { Setuju }\end{array}$} & \multicolumn{2}{|c|}{$\begin{array}{c}\text { Sangat } \\
\text { Tidak Setuju }\end{array}$} \\
\hline & & $\mathrm{F}$ & $\%$ & $\mathrm{~F}$ & $\%$ & $\mathrm{~F}$ & $\%$ & $\mathrm{~F}$ & $\%$ & $\mathrm{~F}$ & $\%$ \\
\hline 1 & Pernyataan 1 & 3 & $8 \%$ & 34 & $89 \%$ & 1 & $3 \%$ & 0 & $0 \%$ & 0 & $0 \%$ \\
\hline 2 & Pernyataan 2 & 10 & $26 \%$ & 26 & $68 \%$ & 2 & $5 \%$ & 0 & $0 \%$ & 0 & $0 \%$ \\
\hline 3 & Pernyataan 3 & 3 & $8 \%$ & 31 & $82 \%$ & 4 & $11 \%$ & 0 & $0 \%$ & 0 & $0 \%$ \\
\hline 4 & Pernyataan 4 & 4 & $11 \%$ & 31 & $82 \%$ & 3 & $8 \%$ & 0 & $0 \%$ & 0 & $0 \%$ \\
\hline 5 & Pernyataan 5 & 7 & $18 \%$ & 28 & $74 \%$ & 3 & $8 \%$ & 0 & $0 \%$ & 0 & $0 \%$ \\
\hline 6 & Pernyataan 6 & 8 & $21 \%$ & 27 & $71 \%$ & 3 & $8 \%$ & 0 & $0 \%$ & 0 & $0 \%$ \\
\hline 7 & Pernyataan 7 & 3 & $8 \%$ & 31 & $82 \%$ & 4 & $11 \%$ & 0 & $0 \%$ & 0 & $0 \%$ \\
\hline 8 & Pernyataan 8 & 6 & $16 \%$ & 28 & $74 \%$ & 4 & $11 \%$ & 0 & $0 \%$ & 0 & $0 \%$ \\
\hline 9 & Pernyataan 9 & 3 & $8 \%$ & 33 & $87 \%$ & 2 & $5 \%$ & 0 & $0 \%$ & 0 & $0 \%$ \\
\hline 10 & Pernyataan 10 & 15 & $39 \%$ & 23 & $61 \%$ & 0 & $0 \%$ & 0 & $0 \%$ & 0 & $0 \%$ \\
\hline & Rata-Rata & & $16 \%$ & & $77 \%$ & & $7 \%$ & & $0 \%$ & & $0 \%$ \\
\hline
\end{tabular}


Pada tabel di atas terlihat bahwa yang menjawab setuju sebanyak $77 \%$, yang menjawab sangat setuju sebanyak 16\%, ini menunjukkan bahwa pelatihan di Hotel Santika Premiere Dyandra Medan sudah cukup baik, di mana pelatihan yang diberikan mencapai sasaran atau tujuannya dan meningkatkan kemampuan dan kinerja karyawan Front of House. Sedangkan responden yang menjawab kurang setuju sebanyak $7 \%$, menunjukkan bahwa pelatih masih harus meningkatkan kualifikasi dan kemampuannya di dalam melatih. Selain itu, pelatih wajib menggunakan metode pelatihan yang sesuai dengan peserta dan memilih peserta yang sesuai dengan topik pelatihan. Namun angka tersebut tidak begitu signifikan dibandingkan dengan angka responden yang setuju dan sangat setuju, sehingga tidak begitu berpengaruh.

\section{Deskripsi data variabel Kinerja}

Tabel 3 Rekapitulasi jawaban responden variabel Kinerja (y)

\begin{tabular}{|c|c|c|c|c|c|c|c|c|c|c|c|}
\hline \multirow[t]{2}{*}{ No } & \multirow[t]{2}{*}{ Pernyataan } & \multicolumn{2}{|c|}{$\begin{array}{l}\text { Sangat } \\
\text { Setuju }\end{array}$} & \multicolumn{2}{|c|}{ Setuju } & \multicolumn{2}{|c|}{$\begin{array}{l}\text { Kurang } \\
\text { Setuju }\end{array}$} & \multicolumn{2}{|c|}{$\begin{array}{c}\text { Tidak } \\
\text { Setuju }\end{array}$} & \multicolumn{2}{|c|}{$\begin{array}{c}\text { Sangat } \\
\text { Tidak Setuju }\end{array}$} \\
\hline & & $\mathrm{F}$ & $\%$ & $\mathrm{~F}$ & $\%$ & $\mathrm{~F}$ & $\%$ & $\mathrm{~F}$ & $\%$ & $\mathrm{~F}$ & $\%$ \\
\hline 1 & Pernyataan 1 & 6 & $16 \%$ & 30 & $79 \%$ & 2 & $5 \%$ & 0 & $0 \%$ & 0 & $0 \%$ \\
\hline 2 & Pernyataan 2 & 7 & $18 \%$ & 28 & $74 \%$ & 3 & $8 \%$ & 0 & $0 \%$ & 0 & $0 \%$ \\
\hline 3 & Pernyataan 3 & 10 & $26 \%$ & 27 & $71 \%$ & 1 & $3 \%$ & 0 & $0 \%$ & 0 & $0 \%$ \\
\hline 4 & Pernyataan 4 & 13 & $34 \%$ & 25 & $66 \%$ & 0 & $0 \%$ & 0 & $0 \%$ & 0 & $0 \%$ \\
\hline 5 & Pernyataan 5 & 13 & $34 \%$ & 24 & $63 \%$ & 1 & $3 \%$ & 0 & $0 \%$ & 0 & $0 \%$ \\
\hline 6 & Pernyataan 6 & 11 & $29 \%$ & 25 & $66 \%$ & 1 & $3 \%$ & 1 & $3 \%$ & 0 & $0 \%$ \\
\hline 7 & Pernyataan 7 & 8 & $21 \%$ & 27 & $71 \%$ & 3 & $8 \%$ & 0 & $0 \%$ & 0 & $0 \%$ \\
\hline 8 & Pernyataan 8 & 9 & $24 \%$ & 28 & $74 \%$ & 1 & $3 \%$ & 0 & $0 \%$ & 0 & $0 \%$ \\
\hline 9 & Pernyataan 9 & 13 & $34 \%$ & 24 & $63 \%$ & 1 & $3 \%$ & 0 & $0 \%$ & 0 & $0 \%$ \\
\hline 10 & Pernyataan 10 & 14 & $37 \%$ & 23 & $61 \%$ & 1 & $3 \%$ & 0 & $0 \%$ & 0 & $0 \%$ \\
\hline & Rata-Rata & & $27 \%$ & & $69 \%$ & & $4 \%$ & & $0 \%$ & & $0 \%$ \\
\hline
\end{tabular}

Pada table di atas terlihat bahwa yang menjawab setuju sebayak $69 \%$, yang menjawab sangat setuju sebanyak 27\%, ini menunjukkan bahwa pelatihan yang diberikan mengurangi komplain dari tamu dan meningkatkan pujian dari tamu. Pelatihan juga meningkatkan pelayanan terhadap tamu. Sedangkan responden yang menjawab kurang setuju hanya sebanyak 4\%, menunjukkan bahwa masalah-masalah yang berhubungan dengan operasional tetap ada namun tidak begitu signifikan dan berpengaruh terhadap kinerja karyawan.

\section{Uji Validitas dan Reliabilitas}

Uji validitas digunakan untuk melihat ketepatan instrumen yang digunakan dalam penelitian. Uji validitas yang digunakan adalah uji validitas menggunakan rumus Pearson, di mana rtabel adalah 0.304 . Instrumen dikatakan valid jika nilai rhitung $\geq \mathbf{r t a b e l}$. Hasil validitas dari setiap instrumen variabel penelitian adalah sebagai berikut: 
Tabel 4 Validitas instrumen variabel Pelatihan (x)

\begin{tabular}{|c|c|c|c|}
\hline \multirow{2}{*}{ Instrumen } & \multicolumn{2}{|c|}{ Nilai Validitas } & \multirow{2}{*}{ Kesimpulan } \\
\hline & rhitung & rtabel & \\
\hline Pernyataan 1 & 0.553 & \multirow{10}{*}{0.304} & Valid \\
\hline Pernyataan 2 & 0.537 & & Valid \\
\hline Pernyataan 3 & 0.577 & & Valid \\
\hline Pernyataan 4 & 0.554 & & Valid \\
\hline Pernyataan 5 & 0.640 & & Valid \\
\hline Pernyataan 6 & 0.733 & & Valid \\
\hline Pernyataan 7 & 0.679 & & Valid \\
\hline Pernyataan 8 & 0.520 & & Valid \\
\hline Pernyataan 9 & 0.443 & & Valid \\
\hline Pernyataan 10 & 0.344 & & Valid \\
\hline
\end{tabular}

Dari tabel 4 terlihat bahwa hasil pengujian masing-masing instrumen variabel pelatihan (x) memiliki nilai r-hitung $>0.304$, dengan demikian secarakeseluruhan instrumen pernyataan dari variabel pelatihan yang digunakan dinyatakan valid.

Tabel 5 Validitas instrumen variabel Kinerja (y)

\begin{tabular}{|c|c|c|c|}
\hline \multirow{2}{*}{ Instrumen } & \multicolumn{2}{|c|}{ Nilai Validitas } & \multirow{2}{*}{ Kesimpulan } \\
\hline & rhitung & rtabel & \\
\hline Pernyataan 1 & 0.727 & \multirow{10}{*}{0.304} & Valid \\
\hline Pernyataan 2 & 0.669 & & Valid \\
\hline Pernyataan 3 & 0.644 & & Valid \\
\hline Pernyataan 4 & 0.705 & & Valid \\
\hline Pernyataan 5 & 0.736 & & Valid \\
\hline Pernyataan 6 & 0.675 & & Valid \\
\hline Pernyataan 7 & 0.660 & & Valid \\
\hline Pernyataan 8 & 0.695 & & Valid \\
\hline Pernyataan 9 & 0.693 & & Valid \\
\hline Pernyataan 10 & 0.740 & & Valid \\
\hline
\end{tabular}

Dari tabel 5 terlihat bahwa hasil pengujian masing-masing instrumen variabel kinerja (y) memiliki nilai r-hitung $>0,304$, dengan demikian dapat disimpulkan bahwa secara keseluruhan instrumen pernyataan dari variabel kinerja yang digunakan dinyatakan valid

Uji reliabilitas dilakukan untuk menjamin instrumen yang digunakan merupakan instrumen yang handal, konsisten dan stabil jika digunakan secara berulang-ulang pada waktu yang berbeda-beda. Instrumen dinyatakan reliabel jika nilai cronbach alfa hitung $>$ cronbach alfa toleransi $(0,6)$. Hasil pengujian reliabilitas adalah sebagai berikut:

Tabel 6 Hasil Reliabilitas Instrumen Penelitian

\begin{tabular}{|c|l|c|c|}
\hline No & \multicolumn{1}{|c|}{ Variabel } & Nilai & Kesimpulan \\
\hline 1 & Pelatihan (x) & 0.771 & Reliabel \\
\hline 2 & Kinerja (y) & 0.918 & Reliabel \\
\hline
\end{tabular}


Hasil uji reliabilitas menunjukkan bahwa nilai Cronbach's Alfa seluruh variabel lebih besar dari 0.6, dengan demikian kuesioner penelitian ini dinyatakan reliabel.

\subsubsection{Hasil Uji Regresi Linear Sederhana}

Pengujian ini dilakukan untuk mengetahui pengaruh pelatihan terhadap kinerja pada Hotel Santika Premiere Dyandra Medan. Berikut hasil pengujian regresi linear sederhana pada masing-masing variabel yaitu:

Tabel 7 Hasil Uji Regresi Linear Sederhana

Coefficients $^{\mathrm{a}}$

\begin{tabular}{|c|c|c|c|c|c|c|}
\hline \multirow[b]{2}{*}{ Model } & & \multicolumn{2}{|c|}{ Unstandardized Coefficients } & \multirow{2}{*}{$\begin{array}{c}\begin{array}{c}\text { Standardized } \\
\text { Coefficients }\end{array} \\
\text { Beta }\end{array}$} & \multirow[b]{2}{*}{$\mathrm{t}$} & \multirow[b]{2}{*}{ Sig. } \\
\hline & & $\mathrm{B}$ & Std. Error & & & \\
\hline 1 & (Constant) & 30.849 & 6.493 & & 4.751 & .000 \\
\hline & PELATIHAN & .299 & .156 & .303 & 1.911 & .064 \\
\hline
\end{tabular}

Berdasarkan hasil pengujian di atas, maka diperoleh persamaan regresi linear sederhana sebagai berikut:

$$
Y=30,849+0,299 x+e
$$

Pada model regresi linear sederhana diperoleh nilai konstanta kinerja sebesar 30,849 , artinya jika nilai variabel bebas $(\mathrm{x})$ nilainya 0 , maka variabel terikat $(\mathrm{Y})$ nilainya sebesar 30,849. Jika nilai variabel bebas (x) naik sebesar satu satuan atau 1, maka variabel terikat (Y) akan naik sebesar 0,299. Koefisien regresi variabel bebas bernilai positif, artinya pelatihan pada Hotel Santika Premiere Dyandra Medan dapat mempengaruhi kinerja karyawan Front of House.

\section{Pengujian Hipotesis}

a. Koefisien Determinasi $\left(\mathrm{R}^{2}\right)$

Koefisien determinasi bertujuan untuk mengukur berapa besar kemampuan variabel bebas dalam menerangkan variabel terikat. Nilai koefisien determinasi dapat dilihat pada tabel berikut:

Tabel 8 Hasil Uji Keofisien Determinasi $\left(\mathrm{R}^{2}\right)$

\begin{tabular}{|c|c|c|c|c|c|c|c|c|c|}
\hline \multicolumn{10}{|c|}{ Model Summary } \\
\hline \multirow[b]{2}{*}{ Model } & \multirow[b]{2}{*}{$\mathrm{R}$} & \multirow[b]{2}{*}{ R Square } & \multirow[b]{2}{*}{$\begin{array}{l}\text { Adjusted R } \\
\text { Square }\end{array}$} & \multirow[b]{2}{*}{$\begin{array}{c}\text { Stdd. Error of the } \\
\text { Estimate }\end{array}$} & \multicolumn{5}{|c|}{ Change Statistics } \\
\hline & & & & & $\begin{array}{l}\text { RSquare } \\
\text { Change }\end{array}$ & F Change & df1 & $\mathrm{d}$ f2 & Sig. FChange \\
\hline & ,303年 & .092 & .067 & 2.30609 & .092 & 3.652 & & 36 & .064 \\
\hline
\end{tabular}

Nilai koefisien determinasi yang diperoleh sebesar 0,092 atau 9,2\% menunjukkan bahwa variabel pelatihan memiliki kemampuan yang kecil di dalam menjelaskan variasi yang terjadi pada kinerja di Hotel Santika Premiere Dyandra Medan, sedangkan sisanya 90,8\% dijelaskan oleh variabel lain yang tidak diteliti dalam penelitian ini seperti manfaat karyawan, lingkungan kerja, jenjang karir dan lainnya.

\section{Uji Parsial (uji t)} kriteria:

Uji parsial (uji t) bertujuan untuk melihat pengaruh pelatihan terhadap kinerja, dengan

1. Jika $t_{\text {hitung }} \leq t_{\text {tabel }}$ maka $\mathrm{H}_{0}$ diterima, $\mathrm{H}_{1}$ ditolak, artinya secara parsial penelitian ini tidak berpengaruh;

2. Jika $t_{\text {hitung }}>t_{\text {tabel }}$ maka $\mathrm{H}_{0}$ ditolak, $\mathrm{H}_{1}$ diterima, artinya secara parsial penelitian ini berpengaruh. 


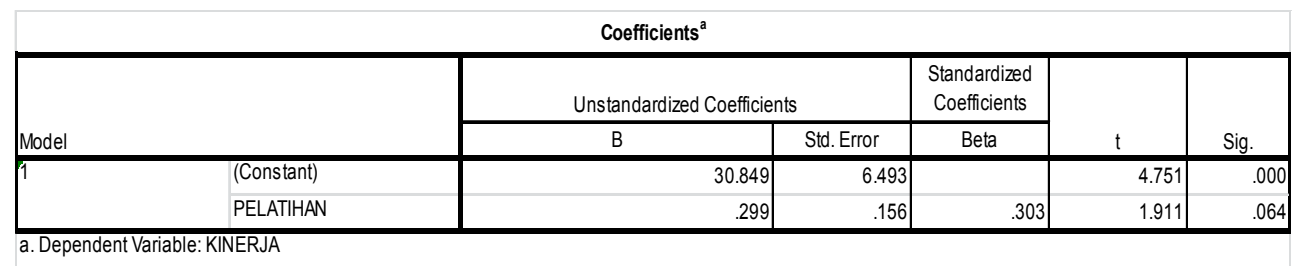

Tabel 4.12 Hasil Uji Parsial (uji t)

Berdasarkan tabel tersebut dapat dilihat bahwa: Nilai thitung untuk variabel pelatihan $1.911>\mathrm{t}_{\text {tabel }} 1.689$, maka $\mathrm{H}_{0}$ ditolak dan $\mathrm{H}_{1}$ diterima, artinya secara parsial variabel pelatihan berpengaruh positif terhadap kinerja.

\section{Pembahasan}

Hasil pengujian hipotesis pertama menunjukkan bahwa variabel pelatihan berpengaruh sedikit terhadap kinerja di Hotel Santika Premiere Dyandra Medan, ini dibuktikan dengan nilai koefisien determinasi $\left(\mathrm{R}^{2}\right)$ yang diperoleh sebesar 0.092 atau 9.2\%, sedangkan sisanya sebesar $90.8 \%$ dijelaskan oleh variabel lain yang tidak diteliti dalam penelitian ini.

Hasil pengujian hipotesis kedua menunjukkan bahwa secara parsial variabel pelatihan berpengaruh positif terhadap kinerja. Hasil penelitian ini sesuai dengan hasil wawancara penulis dengan Taining Executive Hotel Santika Premiere Dyandra Medan, bahwa pelatihan memperbaiki kinerja karyawan. Masalah di dalam operasional hotel tetap ada namun tidak begitu signifikan.

\section{Kesimpulan}

Berdasarkan hasil penelitian dan pembahasan pada bab sebelumnya, maka kesimpulan yang didapat adalah sebagai berikut:

1. Secara parsial pelatihan berpengaruh positif terhadap kinerja karyawan Front of House pada Hotel Santika Premiere Dyandra Medan.

2. Variabel pelatihan memiliki pengaruh yang sedikit terhadap variabel kinerja di Hotel Santika Premiere Dyandra Medan. Hal ini dibuktikan dengan nilai koefisien determinasi $\left(\mathrm{R}^{2}\right)$ yang diperoleh sebesar 0.092 atau $9.2 \%$, sangat jauh di bawah $100 \%$.

3. Secara keseluruhan instrumen pernyataan dari variabel pelatihan dan kinerja yang digunakan dinyatakan valid.

4. Hasil uji reliabilitas menunjukkan bahwa kuesioner penelitian ini dinyatakan reliabel. 


\section{REFERENCES}

77.

Arikunto, S. 2010. Prosedur Penelitian: Suatu Pendekatan Praktik. Rineka Cipta, Jakarta.

Cece. (2003). Analisis Hubungan Perencanaan Strategi Aliansi PDAM Tirtanadi-PT. Telekominikasi Divre I Terhadap Peningkatan Kualitas Pelayanan Pelanggan PDAM Tirtanadi... Universitas Sumatera Utara.

Daft, R. L. (2012). New Era of Management (10 $10^{\text {th }}$ ed.). China: South Western, Cengage Learning, International Edition.

DeCenzo, D. A., Robbins, S. P., \& Verhulst, S. L. (2013). Human Resource Management $\left(11^{\text {th }}\right.$ ed.). Singapore: Wiley, International Student Version.

Dessler, Gary. 2016. Human Resources Management, Tenth Edition. Pearson, New Jersey.

Dewi, S. P., \& Hidayat, R. (2014). Pengaruh Net Profit Margin dan Return on Assets terhadap Harga Saham pada Perusahaan Otomotif yang terdaftar di Bursa Efek Indonesia. Jurnal Ilman, 1(1), 110 .

Dinamika, S. G. (2018). Gemstone Fever Hits Jakarta: A Lexical Meaning Analysis.

Dinamika, S. G., \& Sari, W. V. (2015). Applied Error Analysis of Comparative Degree Sentence Construction of Students in STIM Sukma Medan. Asian EFL Journal, 5, 112-119.

Dinamika, Soraya Grabiella (2014) THE EFFECT OF USING COLLABORATIVE STRATEGIC READING ON STUDENTS' ACHIEVEMENT IN READING NARRATIVE TEXT. Undergraduate thesis, UNIMED

Fadli, M., Syarif, H. K., \& Priatna, A. (2015). pengaruh-pelatihan-terhadap-kinerja-karyawanhotel-grand-cempaka-resort-convention-cipayung-bogor-14-1024.

Fathimah, V. (2017). Pengaruh Perkembangan Jumlah Tabungan, Deposito dan Bagi Hasil terhadap Jumlah Pembiayaan yang Diberikan oleh Perbankan Syariah di Sumatera Utara. Jurnal Ilman, $5(1), 41-52$.

Hayes, D. K., \& Ninemeier, J. D. (2016). Human Resources Management in the Hospitality Industry $\left(2^{\text {nd }}\right.$ ed. $)$. United States of America: Wiley.

Hidayat, R. (2010). Analisis Tingkat Penggunaan Internet Dikalangan Mahasiswa dan Hubungannya dalam Peningkatan Nilai Akademik (Studi Kasus pada Mahasiswa di Kota Medan). Jurnal Mediasi, 2(2), 55-63.

Hidayat, R. (2015). Performance Appraisal sebagai Alat Pengukuran Kepuasan Kerja Karyawan. Jurnal Ilman, 3(1), 1-8.

Larasati, Sri. 2016. Excellent Hotel Operation, Cetakan Pertama. Ekuilibira, Yogyakarta.

Mangkunegara, Prabu Anwar. 2013. Manajemen Sumber Daya Manusia Perusahaan, Cetakan kesebelas. PT Remaja Rosdakarya, Bandung.

Nasution, W. A. (2009). Pengaruh kepuasan kerja karyawan terhadap intensi turnover pada call center Telkomsel di Medan. Jurnal Mandiri, 4(1), 1-11.

Nasution, W. A. (2013). Pengaruh kompensasi dan lingkungan kerja terhadap kepuasan kerja karyawan pada PT. Karya Deli Stelindo Medan. Jurnal Manajemen Bisnis STIE IBBI, 20(2), 1-

Nasutiona, L. K., Fahrurb, M., Christine, Imaduddind, \& Wardayani. (2017). The Calculation of Cost of Goods Sold "Gayo Arabica Coffee from Takengon" with Variable Costing Method. Journal Online Jaringan COT POLIPD (JOJAPS), 10, 82-87.

Ningratri, Y. A. (2017). Analisis Pengaruh Strategi Bauran Pemasaran Jasa (3P) terhadap Keputusan Mahasiswa Memilih STIM Sukma Medan. Riset \& Ejurnal Manajemen Informatika, 3(1), 5056. 
Nurlinda, \& Wardayani. (2014). Pengaruh Partisipasi Penyusunan Anggaran Dan Penggunaan Instrumen Manajemen Terhadap Kinerja Pengelolaan Dana Bantuan Global Fund Komponen Aids Pada Kementerian Kesehatan Ri. Jurnal Ilman, 1(1), 23-35.

Prana, R. R. (2016). Analisis Faktor-faktor yang Mempengaruhi Pendapatan Asli Daerah (PAD) Kota Tebing Tinggi. Jurnal Ilman, 4(1), 74-86.

Raidani, Pertiwi, L. S., Wulandari, D. Y., \& Zuhri. (2016). Tobit and Interval Censored Regression Model. Global Journal of Pure and Applied Mathematics, 12(1), 981-994.

Safriandi, F., Pertiwi, L. S., Fitriani, A., \& Zuhri. (2016). Truncated Regression Model and Nonparametric Estimation for Gifted and Talented Education Program. Global Journal of Pure and Applied Mathematics, 12(1), 995-1002.

Saputra, R. A. (2015). Pengaruh Pelatihan Terhadap Kinerja Karyawan Kurir Perusahaan PT. TIKI (Titipan Kilat) Kota Sukabumi. Widyatama Repositori, Bandung.

Sedarmayanti, 2011. Manajemen Sumber Daya Manusia, Reformasi Birokrasi dan Manajemen Pegawai Negeri Sipil (cetakan kelima). PT Refika Aditama, Bandung.

Sekaran, U., \& Bougie, R. (2016). Research Methods for Business $\left(7^{\text {th }}\right.$ ed.). Italy: Wiley.

Septian, R. (2013). Pengaruh Pelatihan Terhadap Kinerja Karyawan ERHA CLINIC Bandung, 0, 5-8.

Sinaga, S., Pertiwi, L. S., Ardian, T., \& Zuhri. (2016). Inventory Simulation Optimization Under Non Stationary Demand. International Journal of Applied Engineering Research, 11(1), 524-529.

Sinuhaji, E. (2010). PENERAPAN LAYANAN UNGGUL DALAM PEMASARAN PRODUK BANK. Jurnal Mediasi, 2(1).

Sinuhaji, E. (2013). PENGARUH BUDAYA ORGANISASI TERHADAP KEPUASAN KERJA KARYAWAN PADA JASA PERHOTELAN (Studi Kasus di Garuda Plaza Hotel Medan). Bisnis Administrasi, 2(1), 2537.

Sinuhaji, E. (2014). Pengaruh Kepribadian, Kemampuan Kerja dan Motivasi Kerja terhadap Kinerja SDM Outsourcing pada PT. Catur Karya Sentosa Medan. Jurnal Ilman, 1(1), 11-22.

Sugiyono. (2012). Metode Penelitian Bisnis (Pendekatan Kuantitatif, Kualitatif, dan R\&D). Bandung: Alfabeta.

Sukendro, H. A. (2012). Pengaruh Citra Merek dan Kualitas Pelayanan terhadap Kepuasan Jama'ah pada Kelompok Bimbingan Ibadah Haji (KBIH) Indosat Medan. Universitas Terbuka.

Suryoadi, Y. (2012). Kompensasi Terhadap Kinerja Karyawan Pada PT . Bank Muamalat Indonesia Cabang Semarang.

Triasmoko, D., Mukzam, M. D., \& Nurtjahjono, G. E. (2014). ( Penelitian pada Karyawan PT Pos Indonesia ( Persero ) Cabang Kota Kediri ). Jurnal Administrasi Bisnis (JAB), 12(1).

Wahyuni, D. S., \& Wardayani. (2016). Analisis Return on Asset, Current Ratio dan Debt Ratio dalam Menilai Kinerja Keuangan pada PT . Pelabuhan Indonesia I (Persero) cabang Belawan. Jurnal Ilman, 4(1), 59-73.

Widjanarko, B. (2015). PENGARUH PEMERIAN KOMPENSASI DAN KOMUNIKASI TERHADAP SEMANGAT KERJA KARYAWAN PADA BUMI KARYA TAMA INSURANCE CABANG MEDAN. Jurnal Research Sains, 1(2), 130-152.

Winata, E. (2015). Pengaruh Disiplin Kerja dan Budaya Kerja terhadap Semangat Kerja Karyawan pada PT. Mayasari Binangun Medan. Research Sains, 1(2), 100-117.

Winata, E. (2015). Pengaruh Pemberian Kompensasi dan Penilaian Prestasi Kerja terhadap Produktivitas kerja Karyawan pada PT. Askrindo cabang Medan. Jurnal Dunia Ilmu, 1(2).

Winata, E. (2017). ANALISA PERAMALAN PENJUALAN DAN PROMOSI PENJUALAN TERHADAP PENINGKATAN VOLUME PENJUALAN PADA PT. CAKRA ANUGERAH ARTA ALUMINDO MEDAN. Research Sains, 3(1). 
Wulandari, A., \& Alamanda, D. T. (2012). Pengaruh Pelatihan dan Disiplin Kerja Terhadap Kinerja Karyawan Pada Yayasan Pendidikan Telkom _ Dini Alamanda - Academia. Jurnal Banking Dan Manajemen Review Ekuitas, 1(1).

Yulianti, E. (2015). Pengaruh Pelatihan Terhadap Kinerja Karyawan Grand Fatma Hotel di Tenggarong Kutai Kartanegara. eJournal Administrasi Bisnis, 3(4), 900-910. Retrieved from ejournal.adbisnis.fisip-unmul.ac.id 